DOI 10.37491/UNZ.73.11

УДК 347.77 .03

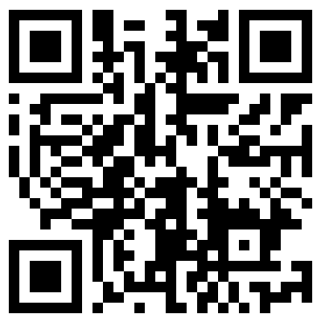

Tetiana G. POPOVYCH${ }^{1}$

\title{
STANDARDS REQUIREMENTS AS A MEANS OF PREVENTION INFRINGEMENT OF INTELLECTUAL PROPERTY
}

The publication proposes to consider standardization as a special tool for regulating public relations, which arise in the field of intellectual property, including in the pharmaceutical industry. It is proposed to apply the requirements of standardization as formal rules, which allow denial of rights in this area. It is noted that despite the common nature all intellectual property have very specific process for the creation, purpose and methods of use. Therefore, these issues are regulated by acts with special content, dedicated to the protection of various intellectual property. The functions of special laws are: complex regulation of relations in the field of use of a particular object, including the public law sphere, detailing the property relations regulated by the Civil Code of Ukraine, definition of all important concepts and terms. They also are a convenient way to fill gaps, as practice detects. Intellectual property must be properly organized and formalized in documents (standardized). Standardization is associated with our products, which are mass, where each unit should not differ from the others. The paradox is that standardization plays a significant role in managing the economy to increase the efficiency and productivity of social production and improve product quality. A characteristic feature of standardization is that its scope and application development level have a wide range. There is no sphere of human activity, which

\footnotetext{
${ }^{1}$ Doctor of Philosophy in Law, Academic secretary,

Academician F. H. Burchak Scientific Research Institute of Private Law and Entrepreneurship of the National Academy of Legal Sciences of Ukraine,

tgpvip@gmail.com,

https://orcid.org/0000-0003-2292-4530.
}

(C) Попович Т. Г., 2020 
was not involved in standardization. With the spread and deepening of knowledge, the development of science and technology, the improvement of production, the scope of work is growing significantly and the scope of application of the principles of standardization is expanding.

From the purpose of standardization we can conclude that it is the organizational and technical basis of all activities at both the national and international levels. Strengthening scientific, technical and economic ties draws attention to the standardization of all developed and developing countries, as well as technical, economic, international, regional and national organizations, businesses and individuals. This is the result of objective necessity streamline management processes and economic production processes. In the field of pharmacopoeia ISO-standards are internationally applicable. These are mostly standards for equipment in the pharmaceutical industry. The standards of the World Intellectual Property Organization are aimed at solving the problem of standardization of patent information and documentation.

The development of intellectual property relations includes the harmonization (adaptation) of Ukrainian legislation to the international standards for regulation of economic relations, to the legislation of international economic unions, including all those unions which Ukraine participates in or plans to participate (including the European Union). In 1997, Ukraine initiated a system of state standards in the field of industrial property and commissioned standards DSTU 3574-97 (Patent form. The main provisions.Drawing up and design) and DSTU 3575-97 (Patent research.The main provisions and procedures).

The author proposes to understand standardization and other means of regulatory influence of the state as those that are able to balance public and private interests, which will allow the development of industries that have mixed regulation, including intellectual property rights. If we consider standardization as a means of regulation is a legal category to achieve a specific result, it is a way to influence the relationship of intellectual property (constraining external factors on the will of the subjects) and the right way (creating formal rules to secure the rights of subjects). This is how the combination of private and public in the field of intellectual property takes place.

Keywords: WIPO standards, DSTU, intellectual property relations, private law, public relations.

$\mathbf{I}_{\mathrm{n}}$ ntellectual property is the subject of civil and economic exchange. It is the result of creative work, that human activity, aimed at creating a spiritual and material values and is a manifestation of something new or improve, enrich and develop the existing one. This result differs from the established and familiar [1]. It is unique, yet not, since its creation and detection (for film) used the established procedures and rules (formulas). These formulas have allowed to define its uniqueness.

Despite their common nature, all intellectual property is quite specific in its process of creation, purpose and methods of use. Therefore, these issues 
are regulated by acts with special content, dedicated to the protection of various intellectual properties. The functions of special laws are complex regulation of relations in the field of use of a particular object, including the public law sphere, detailing the property relations regulated by the Civil Code of Ukraine, definition of all important concepts and terms. They also are a convenient way to fill gaps that detects practice. Such special laws include the laws of Ukraine «On Copyright and Related Rights» of 23.12.1993 № 3792-XII, "On the distribution of copies of audiovisual works, phonograms, videograms, computer programs, databases» of 23.03.2000 № 1587-III, «On peculiarities of state regulation of business entities related to production, export, import of disks for laser reading systems» from 17.01.2002 № 2953-III, «On protection of inventions and utility models» from 15.12.1993 № 3687-XII, «On protection of rights to industrial designs» of 15.12.1993 № 3688-XII, «On protection of rights to plant varieties» dated 21.04.1993 № 3116-XII, "On protection of rights to marks for goods and services» dated 15.12.1993 № 3689-XII, "On protection of rights to indicate the origin of goods» dated 16.06.1999 № 752-XIV, "On protection of rights to the topography of integrated circuits» from 05.11.1997 № 621/97-VR, «On breeding in animal husbandry» dated 15.12.1993 № 3691-XII, «On protection against unfair competition» dated 07.06.1996 № 236/96-VR, «On protection of economic competition» dated 11.01.2001 № 2210-III.

Many regulations (Cabinet of Ministers of Ukraine, Order of the State Department of Intellectual Property, Ministry of Education and Science of Ukraine) devoted to state registration of intellectual property rights, issuance of security documents, establishment of minimum rates of remuneration for use, issuance of compulsory licenses for industrial property, establishment of licensing conditions for certain activities in this area, accounting for collective management organizations and patent attorneys and others.

Strange as it may sound, intellectual property must be properly organized and formalized in documents (standardized). Standardization is associated with our products, which are mass, where each unit should not differ from the others. The paradox is that standardization plays a significant role in managing the economy to improve the effectiveness and efficiency of social production and improve product quality. It accumulates the latest advances in science and technology, combines basic and applied science, promotes rapid introduction of scientific achievements into practice and helps determine the most economical and promising areas of science and technology and various sectors of the economy.

A characteristic feature of standardization is that its scope and application, the level of development have a wide range. There is no sphere of human activity, which was not involved in standardization. With the spread and deepening of knowledge, the development of science and technology, the improvement of production, the scope of work is growing significantly and the scope of application of the principles of standardization is expanding.

The aim of standardization is to establish provisions to ensure that the standardization of its purpose facilities and their safety for life, health and property of people, conservation of animals, plants and protection of the envi- 
ronment, creating conditions for rational use of all national resources, promote removal technical barriers to trade and increasing the competitiveness of products to the level of development of science, technology and the development of international economic, scientific and technical cooperation. Achieving this goal is carried out through the development, implementation and application of regulatory and technical documents. Standardization according to purpose has different tasks.

With the purpose of standardization can understand that it is the organizational and technical basis of all activities at both the national and international levels. Strengthening the scientific, technical and economic relations draws attention to the standardization of all developed countries and developing countries, as well as technical, economic, international, regional and national organizations, businesses and individuals. This is a consequence of the objective need to streamline the management of economic and production processes [2].

In the field of pharmacopoeia internationally applicable standards series ISO. These are mainly standards for pharmaceutical industry equipment (ISO 21976: 2018, ISO / CD 23416 and ISO 11418 series of standards), but ISO already has a separate direction for medicaments, including medical prescriptions and medicinal herbs (ISO 18664:2015, ISO 19610:2017, ISO 19617:2018, ISO 20333:2017, ISO 20334:2018, ISO 20409:2017, ISO 20759:2017, ISO 21314:2019, ISO 21315:2018, ISO 21316:2019, ISO 21370:2019, ISO 21371:2018, ISO 22212:2019, ISO 22584:2019, ISO/FDIS 22590, ISO 22988:2020, ISO/TR 23021:2018, ISO/TR 23022:2018, ISO/TR 23975:2019, serial ISO 18668). The latest standards apply to Traditional Chinese Medicine, but we believe that other medicaments or including medical prescriptions and medicinal herbs will be included in such lists.

The standards of the World Intellectual Property Organization are aimed at solving the problem of standardization of patent information and documentation. It developed member states of the World Intellectual Property Organization international standards relating to information and documentation in the field of industrial and containing recommendations and technical specifications for the uniform methods of presentation of patent information in different media. They are not mandatory for use, but can be used in the preparation, presentation and publication of patent documents and documents of trademarks and industrial designs. They are regulated: the form and content of patent documents; rules of their indexing, classification and coding; content and structure of official bulletins and indexes to them; characteristics of material information carriers, etc. Most patent offices adhere to these standards, which contributes to the harmonization and unification of patent documentation with international standards, provides more effective international cooperation in the field of patent documentation and standardization and integration of global patent information resources, allows to overcome the language barrier. Users of patent information will find knowledge of the current versions of the standards of the World Intellectual Property Organization useful in the search and analysis of patent documentation of the world. 
The standards of the World Intellectual Property Organization in accordance with their purpose, they are divided into four groups:

1) general standards relating to information and documentation (4 standards);

2) standards regarding patent information and documentation (28 standards, 3 of which have a total of 13 applications);

3) standards regarding information and documentation on trademarks (7 standards);

4) standards for information and documentation on industrial designs (3 standards) [3].

Much of the current standards of the World Intellectual Property Organization are used in Ukraine to ensure the preparation and publication of patent documentation, as well as the international exchange of patent documentation [4]. The most popular among users of patent information are standards that contain numeric codes INID (international numeric codes for identification data), in which data are on the first page of a patent document and / or in the Official Gazette can be identified without knowledge of languages and patent legislation, as well as Conventions and Agreements. One of the main and important tools of patent information search is the International Patent Classification, because in the course of patent search using indices International Patent Classification as a universal search tool allows the general public around the world to quickly find the necessary patent information. In Ukraine, some standards of the World Intellectual Property Organization are not fully applied (as in most countries) - only some of its provisions are taken into account [5]. For example, regarding the publication of information on corrections (correction of obvious errors) and changes (in whole or in part).

In general, the standards of the World Intellectual Property Organization are a very important component of the process of creating patent documents and their use, and knowledge of these standards helps users of patent information to search for patents and analyze patent documents. The traditional participation of Ukrainian experts in the implementation of projects of the World Intellectual Property Organization regarding the development of new international standards, revision of existing standards, amendments and additions, as well as providing information on patent documentation of Ukraine to the World Intellectual Property Organization and the European Patent Office. on the one hand, to submit their proposals in the process of such work, and on the other - to promptly take into account changes in the standards of the World Intellectual Property Organization, in relevant areas of the state system of legal protection of intellectual property and, in particular, in patent information of national patent users information.

The development of intellectual property relations involves the harmonization (adaptation) of Ukrainian legislation with international standards for regulating economic relations, the legislation of international economic unions, which includes or plans to include Ukraine (including the European Union). Thus, the Law of Ukraine "On the National Program of Adaptation of Legislation of Ukraine to the Legislation of the European Union» of 16.03.2004 № 1629-IV and bylaws (Decree of the President of Ukraine «On 
the organization of the Law of Ukraine», «On the National Program of Adaptation of Legislation of Ukraine to Legislation Of the European Union» dated 21.08.2004 № 965/2004, the Regulation on the Center for European and Comparative Law approved by the order of the Ministry of Justice of Ukraine dated 28.10.2004 № 126/5 and others) provides for a number of measures aimed at ensuring the implementation of this direction of national improvement. legislation.

In 1997, a system of state standards in the field of industrial property was introduced in Ukraine, and on January 1, 1998, by order of the State Standard of Ukraine of June 6, 1997, the following standards came into force:

1) DSTU 3574-97 Patent Form. The main provisions. The order of compilation and design;

2) DSTU 3575-97 Patent research. The main provisions and procedures $[6 ; 7]$.

These standards were developed in accordance with the current legislation of Ukraine in the field of industrial property. These requirements are mandatory for business entities operating in the Ukraine, whose activities are wholly or partly financed from the state budget. For all other business entities, the requirements of the standards are of a recommendatory (voluntary) nature.

Only in 2007 another standard was adopted - National Standard № 4 «Assessment of intellectual property rights» (approved by the Cabinet of Ministers of Ukraine from 03.10.2007 № 1185). The standard became mandatory for the application of evaluation activity in the evaluation of intellectual property rights, as well as persons who perform under the legislation review of relevant evaluation reports.

In my opinion, standardization and other means of regulatory influence of the state will be able to balance public and private interests, which will allow the development of industries that have mixed regulation, including intellectual property rights. If we consider standardization as a means of regulation, ie a certain legal category in order to achieve a specific result, it is a means of influencing intellectual property relations (restraining external factors regarding the will of subjects) and a means of exercising the right (creating formalized rules to consolidate the rights of subjects). This is how the combination of private and public in the field of intellectual property takes place.

A comparative analysis of foreign legislation with domestic law reveals that in some foreign countries, especially the United States, Portugal, many rules and even institutions of intellectual property law are intertwined and relate to administrative, civil, economic and other areas of law. Thus, the scope of legislation on intellectual property rights has expanded so much that a mixed type of legal regulation is fundamental in the intellectual property law of these countries (as in Ukraine).

In the science of intellectual property law, regulation is understood as a mechanism of application of original regulations, obligations and prohibitions by means of legal means of law enforcement (use of rights, performance of duties, observance of prohibitions, application of law). 
We believe that standardization as a legal means to regulate the relations of intellectual property is characterized by certain features:

1) a social value because it provides reaching the set goals;

2) reflects the informational qualities of law;

3) in combination with other means, creates conditions for the operation of law;

4) raises certain legal consequences;

5 ) is provided by the coercive force of the state.

In general, we can say that standardization as a means of regulating legal relations in the field of intellectual property is manifested through the rules provided by law (standards, rules, requirements, norms, forms), which are decisive for the emergence of intellectual property relations, the legal status of their participants, legal regime of intellectual property objects, performance of duties by right holders). Therefore, standardization as a means (instrument) regulating relations has universal application, since its requirements:

a) influencing all relationships;

b) create conditions for their emergence and implementation;

c) provide an opportunity to translate social (non-legal) norms into the legal field;

d) in case of non-compliance or non-compliance is the basis for the emergence of a protective legal relationship.

Here we can even talk about absolute liability (as a type of protective legal relationship) in the field of intellectual property, which arises on the basis of violations of statutory and/or contractual, including declared standardized requirements.

As a result, it should be noted that the acts regulating relations in the field of intellectual property in Ukraine is not confined to national regulations. These may also include local acts, which are not so much a «mediator» between centralized legislation and a specific business entity, as should become a modifier that translates the general requirements into specific procedures, implementing these rules in the daily activities of business entities. The subject of local acts is the joint activities of entities (parts of business entities, members, participants, employees) that have entered into legal relations within a single business entity. In this regard, local rule-making is aimed at streamlining, normalization of social relations, which are formed within a given local legal location. The legislator gives economic entities the opportunity to develop the terms of cooperation themselves, to determine by agreement of the parties or unilaterally the creation of local norms. The norms adopted by them are obligatory rules of proper behavior for all parts of business entities, members, participants, employees. Local rule-making depends on the level of legal culture and legal consciousness of those involved in the creation of these rules. The importance of legal culture, legal awareness and legal education has been mentioned infrequently, but at all times. In our opinion, it is from the legal culture and legal consciousness of individuals who create local acts for business entities that the creation of such a system of local legal norms depends, which should adequately reflect the conditions of 
economic, production and technological activities of this entity. Legal regulation with the help of local norms leads to raising legal regulation to a new level, makes it adequate to the past stage of development of society and in this sense has a constructive impact on it. Advance regulation serves as a way to resolve contradictions in the development of the legal form itself. Such regulation shows the need to change legal norms that have come into conflict with the needs of life, or their abolition, the adoption of new ones that reflect the trends of social development. Local regulation shows the shortcomings of legislative regulation, acts as a form of criticism of existing regulations.

\section{References}

1. Попович T. Г. Свропейський Союз: перспективи для українських підприемств. Норлативно-правове забезпечення євроатлантичної інтеграиї̈ Украӥни: матеріали міжн. наук.-практ. конф. 24 вересня 2004 р. Серія «Дослідження і розробки у сфері евроатлантичної інтеграції України». Вип. 1. Київ, 2004. С. 159-161.

2. Попович T. Г. Зміна правових засад у сфері технічного регулювання в Україні відповідно до вимог СС. Приватне право $і$ підприєлниитво. Вип. 16. Київ, 2016. С. 141-144.

3. WIPO Standards, Recommendations and Guidelines. The World Intellectual Property Organization. URL : https://bit.ly/3c17Owc.

4. Методические рекомендации по проведению патентных исследований. Москва : ВНИИПИ, 1988. 174 с.

5. Патентні дослідження / за ред. В. Л. Петрова. К. : Ін Юре, 1999. 264 с.

6. Патентні дослідження. Основні положення та порядок проведення: ДСТУ 3575-97 / розробн.: Г. П. Крайчинська, Г. П. Добриніна, В. П. Герчанівська та ін. К. : Держстандарт України, 1997. 14 с.

7. Система розроблення та поставлення продукції на виробництво. Основні терміни та визначення: ДСТУ 3278-95 / розробн.: В. С. Тимошенко, Г. Г. Бакунова. Київ : Держстандарт України, 1996. $40 \mathrm{c}$.

Надійшла до редакції 01.02.2020

\section{Тетяна ПОПОВИЧ}

Науково-дослідний інститут приватного права і підприелнищтва імені академіка Ф. Г. Бурчака Національної академї̈ правових наук України (м. Київ)

\section{Вимоги стандартів як засіб профілактики посягань на інтелектуа- льну власність}

Пропонуеться розглядати стандартизацію як особливий засіб для регулювання суспільних відносин, що виникають у сфбері інтелектуальної власності, в толу числі у фбарлацевтичній галузі. Пропонуеться застосовувати вимоги стандартизаиії як формалізовані правила, що дозволяють запобігти порушеннял прав у иій сфбері. Зазначається, що, незважаючи на спільне походження, всі об'єкти інтелектуальної власності досить специфбічні за процесом створення, призначеннял $і$ способами використання. Толу иі питання регулюються актами зі спеціальним злістом, шо присвячені охороні різних об'єктів інтелектуальної власності. Функиіями спеціальних законів е комплексне регулювання відносин у сфбері використання того чи іншого об’екта включаючи разол із публічно-правовою сферою, деталізацією врегульованих Цивільним кодексол Украйни 
майнових відносин, визначенням усіх важливих понять $і$ терлінів. Також вони залишаються зручним засобол заповнення прогалин, що виявлятиме практика.

Інтелектуальна власність має бути належним чином упорядкована та форлалізована у документах (стандартизована). Стандартизаиія асоиіюеться у нас з продукиією, що є масовою, де кожна одиниия не повинна відрізнятися від інших. Парадокс у тому, що стандартизація відіграе суттеву роль під час управління економікою для підвищення ефбективності й продуктивності суспільного виробництва та поліпшення якості продукиї̈. Характерною особливістю стандартизації є те, що сбера ї̈ дії та застосування, рівень розвитку мають широкий діапазон. Нелає такої сфбери діяльності людини, до якої б не була причетна стандартизаціл. 3 поширенням $i$ поглибленням пізнання, розвиткол науки і техніки, удосконаленнял виробнищтва масштаби робіт значно зростають $і$ поширюеться сфбера використання приниипів стандартизаиії. 3 мети стандартизацію можна зрозуміти, що вона є організаційно-технічною основою усіх видів діяльності як на національному, так $і$ на міжнароднолу рівнях. Зліинення науково-технічних та економічних зв'язків привертає увагу до стандартизаиї усіх розвинених країн світу та країн, що розвиваються, а також технічних, економічних, міжнародних, регіональних $і$ національних організацій, бізнесу та окрелих осіб. Це є наслідком об'єктивної необхідності упорядкування проиесів управління еконолічнили $і$ виробничили процесали. У сфбері барлакопеї на міжнароднолу рівні застосовується низка стандартів ISO. Це переважно стандарти для обладнання фарлацевтичної промисловості. На вирішення проблели стандартизації патентної інфбормацї та документації спрямовані стандарти Всесвітньої організації інтелектуальної власності.

Розвиток відносин інтелектуальної власності передбачає гарлонізацію (адаптацію) законодавства України з міжнародними стандартали регулювання відносин у сфьері господарювання, законодавствол міжнародних еконолічних союзів, до складу яких входить чи плануе увійти Украйна (разол із Свропейським Союзом). У 1997 році в Україні започатковано систему державних стандартів у галузі промислової власності та з 1 січня 1998 р. наказом Держстандарту України від 6 червня 1997 р. № 327 дію набули чинності такі стандарти: 1) ДСТУ 3574-97 Патентний фборлуляр. Основні положення. Порядок складання та офборллення; 2) ДСТУ 3575-97 Патентні дослідження. Основні положення та порядок проведення. Пропонуеться розуміти стандартизацію та інші засоби регулюючого впливу держави як такі, що здатні урівноважити публічні та приватні інтереси, що дозволить розвиватися галузял, які мають змішане регулювання, у тому числі праву інтелектуальноӥ власності. Якщо розглянути стандартизацію як засіб регулювання, тобто певну юридичну категорію з метою досягнення конкретного результату, то вона є засобом впливу на відносини інтелектуальної власності (стримуючі зовнішні ббактори щодо волі суб’єктів) та засобом реалізащї права (створення фборлалізованих правил для закріплення прав суб'єтів). Саме так відбувається поєднання приватного та публічного у сфбері інтелектуальної власності.

Ключові слова: стандарти ВОІВ, ДСТУ, відносини інтелектуальної власності, приватне право, публічні відносини. 